To link to this article / Para enlazar con este artículo:

https://doi.org/10.14198/fem.2020.35.05

To cite this article / Para citar este artículo:

Cohen, Sue y Samzelius, Tove. "Through the lens of single parenthood: a comparative snapshot of the impact of neoliberal welfare, housing and employment policies on single mothers in the UK and Sweden». En Feminismo/s, 35 (junio 2020): 127-153. Monographic dossier / Dossier monográfico: A critical practice of thinking otherwise: Bacchi, Gender and Public Policy Analysis, coord. Angela O'Hagan, DOI: 10.14198/ fem.2020.35.05

\title{
THROUGH THE LENS OF SINGLE PARENTHOOD: A COMPARATIVE SNAPSHOT OF THE IMPACT OF NEOLIBERAL WELFARE, HOUSING AND EMPLOYMENT POLICIES ON SINGLE MOTHERS IN THE UK AND SWEDEN
}

\author{
A TRAVÉS DE LA LENTE DE LA MATERNIDAD SOLTERA: \\ UNA INSTANTÁNEA COMPARATIVA DEL IMPACTO \\ DE LAS POLÍTICAS NEOLIBERALES DEL ESTADO \\ DEL BIENESTAR. VIVIENDA Y EMPLEO EN LAS MADRES \\ SOLTERAS DE REINO UNIDO Y DE SUECIA
}

\author{
SUE COHEN \\ University of Bristol, Bristol \\ sue.cohen@bristol.ac.uk \\ orcid.org/0000-0002-8831-7963 \\ TOVE SAMZELIUS \\ Malmö University, Malmö \\ tove.samzelius@mau.se \\ orcid.org/0000-0003-3641-5542
}

\begin{abstract}
The paper considers why feminists working on gender mainstreaming in the UK looked to Sweden for models to effect structural change and why in recent years the models in Sweden are deficient, embodying an ever-increasing blind spot to the socio/economic constraints experienced by single parents, migrant mothers the most marginalised. Referencing academic feminist research in Sweden and the UK, as well
\end{abstract}


Through the lens of single parenthood: a comparative snapshot of the impact of neoliberal welfare, housing and employment policies on single mothers in the UK and Sweden

as participatory research over many years involving single mothers, the paper examines why poverty is more entrenched in the UK: how in both countries neo-liberal trajectories of welfare, employment and housing policies are increasingly similar with exclusionary outcomes; how the position of single mothers acts is a touchstone for persistent intersectional inequalities in both countries. We conclude that by examining welfare, housing and employment policies through the lens of single parenthood, feminists can better re-frame strategies informed by the reproductive economy furthering the socio/economic independence of female headed households.

Keywords: Single mothers; UK; Sweden; Gender analysis; Social Security.

\section{Resumen}

Este artículo estudia por qué las feministas que trabajan en una perspectiva integrada de género en el Reino Unido se han acostumbrado a mirar a Suecia para buscar cambios estructurales efectivos, y por qué en los últimos años los modelos suecos son deficientes, a la vez que ejemplifican un punto muerto cada vez mayor respecto a las limitaciones socioeconómicas que viven las familias monoparentales, siendo las madres migrantes las más marginalizadas. Si tomamos en cuenta tanto la investigación académica feminista como la investigación participativa llevada a cabo en Suecia y el Reino Unido durante muchos años en lo que concierne a las madres solteras, el estudio examina por qué la pobreza está más arraigada en el Reino Unido; cómo ambos países, de trayectorias neo liberales, en cuanto a las políticas de bienestar social, empleo y vivienda, son cada vez más similares y muestran resultados de exclusión; y cómo la situación de las madres solteras es una piedra angular en las persistentes variables de desigualdad y discriminación en ambos países. Consideramos que, si examinamos el bienestar social, la vivienda y las políticas de empleo desde la perspectiva de las familias monoparentales, el feminismo debe reformular estrategias basadas en la economía reproductiva no remunerada que favorezcan la independencia socioeconómica de los hogares encabezados por mujeres.

Palabras clave: madres solteras; Reino Unido; Suecia; análisis de género; Seguridad Social.

\section{BACKGROUND}

Many feminist activists, practitioners and academics working on gender mainstreaming in the UK had previously looked to Sweden for inspiration to effect structural change (Kiernan, Land and Lewis 144). The reasons for this were historical. While many of the fundamental principles underpinning the early

Feminismo/s 35, junio 2020, pp. 127-153 
Through the lens of single parenthood: a comparative snapshot of the impact of neoliberal welfare, housing and employment policies on single mothers in the UK and Sweden

British and Swedish welfare states were based on patriarchal ideologies, the gender regimes began to diverge in the 1960s. The booming Swedish post-war economy opened up new opportunities for women, who were encouraged to enter the labour market. To support the increasing number of mothers moving into paid employment at the time, a host of «family friendly» policies were introduced and publicly funded childcare was expanded, benefiting single mothers and their children.

The guiding principle of social policy towards single mothers in Sweden has, since, the 1970s, been one of integration and inclusion within policies for gender equality and labour market participation. To a large extent it was the combination of labour-market participation, redistribution and support services that enabled a majority of single mothers to escape the poverty trap (Hobson and Takahashi 121-139). In contrast, single mothers in the UK endured high rates of unemployment and poverty, effectively abandoned by the state under Conservative rule 1979-1997. Many also faced discrimination on the housing and labour markets due to their status as «single». The Swedish model was seen to come closest to solving the economic problems of one parent families, compared to the UK where gendered inequality was proving especially harmful to one parent families. The more unequal the society, the greater the difference between men and women and the greater the difference between rich and poor, the worse single parents seemed to be doing (Kiernan, Land and Lewis 138-145), a virulent contagion where patriarchy and poverty enmesh.

In the UK, a male worker model continued to underpin employment policies up to the end of the $20^{\text {th }}$ century. Women had always been present in the workplace, but to succeed many had to become like men, working long hours, with little flexibility, or if they were mothers, settle for part-time low paid employment that could be organised around childcare needs. For two parent families, this was eased somewhat with a male earner in the family. However, single mothers were particularly disadvantaged given that the infrastructure of the work place had historically failed to integrate the needs of parents or indeed motherhood into the equation (Kiernan, Land and Lewis 242-275). There was some progress under New Labour including tax credits and greater investment in childcare provision. Progressive improvements in employment protections were also fought for and achieved by women

Feminismo/s 35, junio 2020, pp. 127-153 
Through the lens of single parenthood: a comparative snapshot of the impact of neoliberal welfare, housing and employment policies on single mothers in the UK and Sweden

NGOs and Trade Union movements at a national and EU level. Single Parent Action Network was part of that movement (Select Committee on Work and Pensions, Memorandum submitted by Single Parent Action Network; Wright and Giullari). The UK was on the cusp of developing an adult worker welfare state that was beginning to include women and care into the equation (Annesley 9-12). However, although New Labour's program represented an improvement for many single mothers, it should also be understood in the broader context of international welfare reform programmes designed to dis-incentivise «welfare dependency». Furthermore, the neoliberal Coalition and Conservative governments' austerity project that followed the Labour government after 2010, and continued the thrust to get more people into work whilst slashing public services by up to $50 \%$, undermined any advances. Single parents and black and minority ethnic women have been the hardest hit (Hall et al.). The adult worker model now prevails, with care no longer on the political agenda (Pearson; Van Lancker).

On the surface, active welfare policies targeting workless single mothers in the UK might appear far removed from the policy context of Sweden where single mothers were already expected to work and where universal affordable childcare continues to cater for the needs of a majority of working parents. However, as we will argue in this paper, there are also worrying similarities, in particular when examining the situation of single mothers disadvantaged by discriminations inherent in class, ethnicity and citizenship status. The ideological underpinnings and the punitive nature of workfare policies targeting marginalized single mothers in both countries are more and more alike. Furthermore, in both countries the most vulnerable single mothers and their children are facing the brunt of a housing crisis that is pushing many into destitution.

\section{FEMINIST CRITIQUES OF THE NEOLIBERAL WELFARE STATE}

In the late 1980s, Nancy Fraser («Women, Welfare» 103) had argued that «social-welfare struggles should become more central for feminists» yet again. She predicted that battles over social spending would soon come to dominate national politics in every late-capitalist welfare state in Western Europe and North America. Women, Fraser said, comprised the overwhelming majority 
Through the lens of single parenthood: a comparative snapshot of the impact of neoliberal welfare, housing and employment policies on single mothers in the UK and Sweden

of social-welfare programme recipients and employees, and therefore would become the main victims of what some analysts had dubbed 'the coming welfare wars'. Fraser concluded that this would lead to what Diane Pearce (28-36) has referred to as the «feminization of poverty». Single mothers, in particular those with weak material and social capital would be hit the hardest.

Over the past 30 years, these «welfare wars» have led to the restructuring and retrenchment of welfare states across Western Europe and North America instigated through neoliberal reforms. During the same period changes in the labour market have led to both the erosion and intensification of gender differences (Fudge and Cossman 24-30). On the one hand, shifts in the labour market have led to a convergence of female and male labour market experiences that are to some extent more polarized in relation to class and ethnicity rather than gender. On the other hand, the intensification of gender differences is more evident in the care and service sectors, where high numbers of women are in low-paid, precarious and often part-time employment (Bezanson 27-40). The gender pay gap remains a constant, over and above these shifts and changes.

Coupled with these changes in the labour market (where increased female participation is often cloaked in a language of gender equality), feminists have critiqued the state's reduction in welfare redistribution that has led to a deficit in «time to care», particularly difficult for low-income single mothers (Fraser, «Capitalism's»). While middle-class women are able to deal with the «care-gap» by buying time through domestic services, this is not an option available to those with less resources and means. Furthermore, although the transformation of social policy is described in terms of shifts of power from the state to the market, and in responsibility from public to private domains, the neoliberal state also develops new regulatory interventions that privilege the market to the detriment of care-giving. Indeed, as argued by Feldman:

While it (neo-liberalism) embraces laissez-faire and promotes the market as an ideal to be championed in all spheres of life, in practice it offers harsh treatment for those at the bottom of the socio-economic order, who do not meet the threshold requirements for being able to be successful market actors (344).

The increased pressure on «the regulation of time» is an issue encountered in our past and present research projects involving low-income single mothers 
Through the lens of single parenthood: a comparative snapshot of the impact of neoliberal welfare, housing and employment policies on single mothers in the UK and Sweden

(Samzelius, Family homelessness 76; Cohen et al. 71-72). This is not only a problem when balancing employment with care. The process of negotiating state regulatory controls can in itself become a stressful, time-consuming exercise. As pointed out by our colleagues in the Productive Margins programme:

In experiential co-produced research participants with experience of poverty are having to negotiate a myriad of regulations in a state controlled environment in which «multiple regulatory domains criss-cross, fragment and overlap.» (McDermont et al. 189)

Policies in the areas of housing, social security, employment and child welfare traverse in complex ways the lives of disadvantaged single mothers (Murphy 250). Yet failure to move forward tends to be cast in terms of a parent's «individual responsibility» (Samzelius, Family homelessness 231). This is the real-life outcome of a persistent discourse and ever-increasing process of individualisation that has spread from one advanced welfare state to another since the 1980s (Giddens; Dwyer; Beck and Beck-Gernsheim). Welfare recipients are nowadays expected to free themselves from need through «a form of self-actualization that revolves around personal responsibility, choice and autonomy» (Mik-Meyer and Villardsen 4). If, as argued by Nancy Fraser, the present strains on care are not accidental, but rather «a more or less acute expression of the social-reproductive contradictions of financialised capitalism» («Crisis of Care?» 22), the impact of individualisation on power-inferior groups might be more detrimental than recognised in political discourses.

Social reproductive conditions for capitalist production have historically assumed different institutional forms and embodied different normative regulatory controls. However, the status of single mothers unable to sustain their families remains unresolved. When inherent inequalities in market economies with regard to gender, ethnicity, class and disability intersect in the lives of one parent families, they struggle to maintain financially secure households. Over time «the problem» of single motherhood has been dealt with by the state through different normative modes. Historically, in both Britain and Sweden, until redistributive welfare policies enabled single women with children to form separate households, the «solution» to «the problem» was often fostering or adoption, while the mother was shamed in to silence. Today, despite an increased societal acceptance of single motherhood, the status of poor single mothers as an anomaly within the capitalist system has

Feminismo/s 35, junio 2020, pp. 127-153 
Through the lens of single parenthood: a comparative snapshot of the impact of neoliberal welfare, housing and employment policies on single mothers in the UK and Sweden

never been resolved (Samzelius, Family homelessness). The «new solution» is workfare in an increasingly regulated and controlling environment. However, as we will discuss in this paper, the intersection of welfare to work policies and housing regulations can work in perverse ways. Regulations can make it difficult for some single parents to find a job or indeed hold down a job that keeps them out of poverty, whilst at the same time having access to secure housing. This disjuncture threatens some families with displacement/homelessness. In their case, the stated policy intent of welfare-to-work policies backfires, with single parent working mothers especially affected; and when ethnicity and citizenship status also intersect, an ever-increasing number of them are black and minority ethnic (BAME) migrant mothers (Reis, A home of her own 10; Reis, Migrant Women.)

\section{THE RESTRUCTURING OF THE WELFARE STATE AND THE IMPACT ON ONE PARENT FAMILIES IN SWEDEN}

When British feminist activists, practitioners and academics working on gender mainstreaming looked to Sweden for models to effect structural change, it was the parent-worker model that was of key interest: In particular, how it seemed to «resource» single mothers through universal affordable wrap-around childcare, a generous parental leave scheme, and, paid leave to care for sick children. The history of the reconciliation of work and family life can be found in debates during the 1960s. The unequal life circumstances of women from different class backgrounds and in particular the situation of single mothers, were central to these debates, at the same time as the booming Swedish post-war economy opened up new opportunities for women who were encouraged to enter the labour market. This created an opening for Swedish feminists to push for further emancipation. Since the early 1970s, female labour-market participation has been a key component of Swedish gender equality policies (Hobson and Takahashi 121-139).

However, if analysed through a broader political/economic lens, the Swedish parent-worker model was not necessarily created on the basis of emancipatory ideals alone, but also in response to the increased need for labour. As single mothers were absorbed in to a model of general «resourcing», enabling mothers to enter the labour market like other members of 
Through the lens of single parenthood: a comparative snapshot of the impact of neoliberal welfare, housing and employment policies on single mothers in the UK and Sweden

society, they benefited from improved living conditions. The Swedish labour market remained highly structured in terms of gender, with women more likely to work part-time and as well as in the expanding public sector. The fragility of this model would come to the fore as the state-managed Swedish welfare state was shaken to its core when the country was hit by a deep fiscal crisis in the early 1990s. In the following years, resources that had previously facilitated the inclusion of low-income single mothers began to be pulled back by both left- and centre-right governments. Among the lasting effects of the welfare retrenchment that took place was the downsizing of social insurance benefit schemes, pension reforms, and the end of full employment as a defining feature of the Swedish welfare state. Gradually, many key functions within the welfare state -for example the care, education and housing sectors- have been de-regularized, de-centralized and privatized to varying degrees. Sweden also saw a shift in labour market policies from a more uniform approach, to a two-tier system where uninsured adults with means tested benefits are referred to secondary activation measures, very similar to those developed in austerity Britain. This latter approach is encapsulated in the discourse on «individual responsibility» and «active citizenship» (Sainsbury and Morrisen).

In the early $21^{\text {st }}$ century, it is clear that those who lost out as a result of these reforms were single mothers and Sweden's refugee population (Gähler; Fritzell, Gähler and Nermo). The proportion of single parents (the vast majority mothers) with a migrant background and low income standard increased from 20\% in 1998 to 56\% in 2017. Single parents born in Sweden (Swedish born) have also been affected, with an increase in those on low income from 9\% in 1998 to $27 \%$ in 2017. During the same period, low income among Swedish-born two-parent households remained consistent around 5\% (Försäkringskassan 9). Between 2003 and 2008, the share of single mothers in temporary employment increased from $12.6 \%$ to $17.5 \%$, whilst decreasing for mothers with a partner from 11.8 to 9.6\% (Jaehrling, Kalina and Mesaros 95).

This means that single mothers are at greater risk of redundancy and have more unstable employment patterns. In a study comparing the prospects for single mothers in France, Germany, Sweden and the UK, Karen Jaehrling, Thorsten Kalina and Leila Mesaros (98) have argued that the overall poverty rate among single mothers in Sweden is lower than elsewhere due to high

Feminismo/s 35, junio 2020, pp. 127-153 
Through the lens of single parenthood: a comparative snapshot of the impact of neoliberal welfare, housing and employment policies on single mothers in the UK and Sweden

levels of full-time employment. However, the relatively low level of income benefits and income protection (through social assistance) makes them vulnerable and increases the risk of poverty in the event of under-employment/ unemployment. Although labour-market participation rates are consistently high, the risk of poverty in this group has risen sharply over the past 20 years, an indication of the policy's limitations.

A recent study conducted by Susan Alm, Kenneth Nelson and Rense Nieuwenhuis, shows the link between welfare state retrenchment and the rising poverty of single-adult households in Sweden between 1988 and 2011. The decline in income replacement in the event of unemployment, stringent qualifying requirements, together with the rise in precarious employment, have contributed to a sharp increase in relative income poverty among unemployed single-earner households (with and without children) in comparison with dual-earner households. The downsizing of old forms of income replacement policies stand in sharp contrast to the development of Swedish work and family reconciliation policies that are mainly benefitting middle-class families, and which have been further expanded.

Those who fail to qualify for first-line benefits are forced to turn to the social assistance scheme for subsistence. There is clear evidence that the cuts to the welfare state initiated in the 1990s have resulted in a 'shift in burden' from social security to means-tested social assistance (Salonen, Övervältringar). Single mothers are over-represented among recipients of social assistance in Sweden and are also more likely to rely on benefits for longer periods of time, making their families particularly vulnerable to persistent poverty and deprivation (Stranz and Wiklund 270). This is problematic for those affected as Sweden makes virtually no exceptions in the means-tested system. You cannot own anything, including a car or a flat, to be eligible for assistance, nor have savings. Assessments are based on a claimant's financial situation rather than needs. Secondly, there is often a stigma attached to means-tested and selective benefits targeting the poor (Sunesson et al. 19). The right to social assistance in Sweden is still built on poor-relief foundations, the idea that relief can never be a right. Fundamental characteristics of the Swedish social assistance scheme are «the duty to accept any job; a willingness to relocate to find work; means testing; discretionary implementation by local officials; 
Through the lens of single parenthood: a comparative snapshot of the impact of neoliberal welfare, housing and employment policies on single mothers in the UK and Sweden

and sanctions if the claimant refuses any of the recommended measures» (Panican and Ulmestig 485).

Despite Sweden's image as «child-friendly», several Swedish studies have shown that decision-making can vary significantly from case to case and that the well-being of children becomes secondary to the activation of their parents (Samzelius, «Ensamstående mammor»; Näsman). The discretionary and localized implementation of welfare conditionality targeting social assistance recipients in Sweden means that activation measures and sanctions are not recorded systematically. Instead, the focus is often placed on caseload reduction and budget savings which means that we know very little about the actual impact on parents and children (Hjort). Interviews with single mothers in the region of Stockholm conducted between 2017 and 2019 however, have uncovered some deeply problematic decisions. For example, homeless mothers have been sanctioned and financial assistance for emergency accommodation has been withdrawn even in situations out of their control, they are still deemed to have broken their claimant commitments (Samzelius, «Ensamstående mammor»).

Neoliberal welfare policies in Sweden target claimants who fail to qualify for the more generous contribution-based income replacement schemes administered through trade unions and the National Insurance Agency. Unlike the UK, that has never developed a parent-worker model, Sweden has continued to resource family friendly policies through generous parental leave, universal access to affordable wrap-around childcare and social security measures that enable working parents to stay at home to look after sick children. Yet, as pointed out by numerous Swedish welfare scholars, such policies primarily benefit parents who are already established in the labour market and exclude those employed in the expanding part-time service and care sectors where zero-hour contracts are rife (Roman; Salonen, Välfärd; Wennberg). In Sweden, unlike its Anglo-Saxon counter parts, the middle-classes (including more established single mothers) are for the time being more protected from crises as described by Fraser ( Crisis of Care?»). This, we argue, has laid the ground for a peculiar form of «poverty blindness» that serves to protect the privilege and status of those who are already «established» in the labour and housing markets, whilst silently excluding the most marginalized one parent families (Samzelius, Family homelessness). 
Through the lens of single parenthood: a comparative snapshot of the impact of neoliberal welfare, housing and employment policies on single mothers in the UK and Sweden

\section{THE RESTRUCTURING OF THE WELFARE STATE AND THE IMPACT ON ONE PARENT FAMILIES IN THE UK}

During the Thatcher and post Thatcher periods under Conservative rule 1979-1997, high numbers of single parents were overly dependent on social security, existing in deeply embedded poverty, stigmatized by political and media discourses. Many single parents wanted to move into paid work but with structured unemployment, and without investment in the childcare infrastructure, this proved deeply challenging (Millar and Ridge; Kiernan, Land and Lewis). When the Labour Government came to power in 1997, $55 \%$ of single parents were not in paid employment (Coleman and Lanceley).

Since that time there has been rapid change. Successive Labour, Coalition and Conservative governments proselytized work as the route out of poverty. By 2019, 69.9\% of single parents were in paid employment (Office for National Statistics, Families). Nevertheless, under Conservative rule single parents have experienced the fastest rise in in-work poverty in the UK, with three in ten employed single parents in poverty by 2018 compared to two in ten in 2010/11 (Joseph Rowntree Foundation UK Poverty 2019/20 31). Whereas Conservative governments in the 1980s and 1990s consigned single parent mothers to welfare dependency, under austerity, neo-liberal driven social welfare policies were re-regulated, with single parent families a specific target. Welfare-to-work policies may mean that single parents are now more likely to be employed, yet at the same time more likely to be trapped within a pernicious intersection of new benefits, housing and employment regulations which together with austerity cuts to public services leave their families increasingly vulnerable to poverty and deprivation (Cohen, The Punitive Impact; Hall et al.).

Although neo-liberalism purports to further the relaxation of regulatory controls, an inherent contradiction in what Feldman describes as the duplicity of the ideology, is that this is belied by the regulation of those in poverty (Feldman 341). Deregulation is designated for the market. Rather than a reduction in the role of the state, the UK neoliberal state now polices single parents, forcing them into employment whilst at the same time reducing state investment in those social infrastructures that would better support caring 
Through the lens of single parenthood: a comparative snapshot of the impact of neoliberal welfare, housing and employment policies on single mothers in the UK and Sweden

responsibilities, time management and family life (Hall et al.). Childcare has largely been handed over to the market.

The Welfare Reform Act 2012 and the roll out of Universal Credit since that time have placed employment over the welfare of the child. Those single parents with young children are the hardest hit, with their mental health particularly affected. (Webb 1). Up until 2008 single parents with children under 16 were not required to work. However, after 2008 the limit was gradually lowered, to 12 and then 7 under the Labour government. The drive to get single parents into work accelerated under the austerity measures of the Coalition government with the limit lowered to 5 years in 2012 and under Conservative rule lowered even further in 2017 for single parents with children over 3. Those single parents not in employment can be sanctioned if judged to be non-compliant with stringent welfare regulations. Yet at the same time they receive the highest proportion of unfair sanctions. From 2012 when the new rules were introduced to $2016,62 \%$ of formal challenges to single parent benefit sanctions were successful. In spite of this success, many of these same families were left in long-term debt (Rabindrakumar 20).

The expectation for parents with young children to be in paid work may have been paralleled in Sweden for many more years, but what is not paralleled is Sweden's significant investment in childcare. The closing of up to 1000 Children's Centres in the era of austerity has meant that quality, accessible childcare in disadvantaged areas is presently at crisis point in the UK (Smith et al.). Under the Labour Government, the welfare of children was better protected, not least because there was state investment in Children's Centres and children were of school age before a single parent was required to work. Cuts to public services and welfare reform under the successive Coalition and Conservative governments have removed those protections.

By 2018, nearly half (49\%) of children in single parent families lived in poverty, compared with one in four in two parent families (25\%) (Joseph Rowntree Foundation, UK Poverty 2018 33). Mothers head 9 out of 10 single parent families in the UK. With tax and benefit changes and cuts to public services, it is estimated that between 2010-2020 they will have experienced an average drop in living standards of $18 \%$ per annum $(£ 8,790)$. Black and Asian households in the lowest fifth of incomes are expected to experience the biggest average drop in living standards of $19.2 \%$ and $20.1 \%$, respectively.

Feminismo/s 35, junio 2020, pp. 127-153 
Through the lens of single parenthood: a comparative snapshot of the impact of neoliberal welfare, housing and employment policies on single mothers in the UK and Sweden

The intersection of structural inequalities further impedes their life chances. Discriminations borne as a result of gender, class, race, citizenship and disability are much more likely to intersect than in two parent families. Single parents are more likely to be disabled (27\%), and more likely to have disabled children (16\%). 19\% of single parents have a BAME background, compared with $14 \%$ of people in the UK (Hall et al.).

Job Centre rulings too often drive single parents into inflexible low paid employment, bringing more problems than solutions, especially when trying to balance childcare (Treanor 65). Over two thirds of single parents enter the three lowest paid occupations (Gingerbread Employment). When compulsory welfare into work measures were first introduced for single parents with children over 7, SPAN and the University of West of England tracked their journey. Of those single parents who found work, all entered the lowest paid jobs - whatever their qualifications - some had degrees but all ended up in cleaning, childcare, and supermarkets (Haux et al. 55-63). Limited social mobility follows from these roles.

Five in every six people in low-paid work fail to escape low pay over 10 years. Barriers to increasing pay can be even greater for those with family responsibilities. Caring for children can limit the number of hours you can work and the distance you can travel for work. (Joseph Rowntree Foundation, UK Poverty 2018 2).

Time poverty as well as material poverty has also become a significant issue for many working single parents.

A single parent on a zero-hours contract will be denied autonomy over parenting time at the same time as earning low and precarious wages. Here, there is no compensating upside. It is the worst of both worlds (Calder 421).

Conversely, under previous Conservative governments single parent members of SPAN for example, had more time for childcare and more space to develop supportive social networks, acting as a form of resistance to stigma and discrimination (SPAN). Now there is little space for self-help groups or collective action. The regulation of time imposed by legislation and prevailing power structures has a knock-on effect on single parents' ability to decide how to use their own time as well as their ability to dissent. If they dissent they may 
Through the lens of single parenthood: a comparative snapshot of the impact of neoliberal welfare, housing and employment policies on single mothers in the UK and Sweden

be punished through sanctions. If they are sanctioned, they have no money to feed their children (Cohen et al. 72).

The introduction of Universal Credit has meant that single parents with children over three are less likely to be prepared for moving into employment than they were a few years ago. They have less time to study, less time to volunteer and develop vocational and non-vocational networks, less time to develop informal childcare support. The Social Security Advisory Committee to the Department of Work and Pensions understood that informal networks helped single parents take control of their lives but that they were largely invisible to Job Centre service providers (Gray and Timmins).

Embedding children's welfare and care in to welfare policies and the delivery of those policies, would help Job Centre advisors to better understand and support the informal networks that sustain and nurture one parent families (Haux et al. 113) and go some way to stemming the deterioration in the lifechances of one parent families with young children. Exemplifying Pearson's assertion that caring responsibilities are not the responsibility of the neoliberal state, Job Centre service providers are required by the neoliberal welfare state to regulate their clients' conduct so that it aligns more closely with the requirements of the market, in particular that they accept individual responsibility for their own poverty (Feldman).

\section{THE FINANCIALISATION OF HOUSING: IMPACT ON ONE PARENT FAMILIES IN SWEDEN AND THE UK}

It is in the everyday struggle involved in working to maintain an independent household, that the unequal positioning of single mothers in poverty is most evident and most difficult. Keeping a roof over one's head is part of that struggle. Although there have been many studies on the impact of welfare and employment policies on single parent families, housing policies have not received the same focus. And yet neo-liberal economic policies that have led to the financialization of housing now intersect in malign ways with the restructuring of welfare in both Sweden and the UK.

In our view, contemporary accounts of poverty in Sweden and the UK can underestimate the complexity of outcomes when housing regulations intersect with social security, employment, and child welfare regulations, increasing 
Through the lens of single parenthood: a comparative snapshot of the impact of neoliberal welfare, housing and employment policies on single mothers in the UK and Sweden

the number of female-headed households that suffer from homelessness and housing exclusion in both countries. (Murphy; Baptista; Bretherton; Mayock, Bretherton and Baptista). There is a growing body of evidence that the experience of homelessness is differentiated by gender, citizenship status and ethnicity (Baptista et al.; Bretherton; Warburton, Whittaker and Papic; Reis, A home of her own). Family homelessness is often hidden or concealed due to a combination of factors including inadequate institutional responses, and the informal strategies used by many mothers in their attempts to find shelter (Baptista; Pleace; Mayock et al.). Migrant women with no recourse to public funds are especially affected in the UK (Reis, A home of her own 36). Likewise evaluation reports in Sweden have shown that where family homelessness is on the increase, families headed by a single migrant mother are disproportionally overrepresented (Samzelius, En plats att kalla hemma). In the latest mapping exercise conducted by the municipality of Stockholm in April 2019, 50\% of the homeless families recorded were headed by a migrant single mother (Samzelius, Family homelessness).

\subsection{Sweden}

From the 1930s to the 1990s, public housing in Sweden was a key element in the country's ambition to construct a housing system that would secure high-quality, affordable housing for all. However, the past 30 years have seen politically initiated changes that have altered the function of the public housing market, in particular in greater Stockholm. The national housing policy has more or less disappeared and left municipalities to decide locally what the public housing sector will look like. Inspired by the British right-to-buy scheme introduced in the 1980s, the Swedish Liberal-Conservative government through a formal decision in 1992, allowed municipalities to convert public rental housing into different market forms. In some municipalities in and around metropolitan Stockholm this meant that all, or at least substantial parts of, the public housing stock was sold off to private housing companies or converted to market-based tenancy owned cooperatives.

During the 21st century, low-income families have found it increasingly difficult to establish themselves in the housing market, especially in the larger cities. Single parent households renting homes in urban areas are struggling 
Through the lens of single parenthood: a comparative snapshot of the impact of neoliberal welfare, housing and employment policies on single mothers in the UK and Sweden

the most (Boverket, Boende till rimlig kostnad). Brett Christophers (885886) refers to the contemporary Swedish housing system as a 'monstrous hybridity'. He argues that it is the housing market's mixed political-economic character that helps to explain why the current Swedish housing system has become so detrimental to the country's most disadvantaged groups. The absence of institutional coordination at a regional level has meant that each municipality has pursued their own housing agendas, which in most cases has been about attracting the middle class, resulting in an underinvestment in affordable rental-housing (Andersson and Magnusson Turner). Although tenancy rights for sitting tenants are strong, direct discrimination based on income and number of household members is legal and creates particular problems for single-earner households with children.

As a result, a growing number of families are unable to access housing through the regular housing market. Instead, they have to look for housing on the unregulated, expensive and insecure sublet market. Between 2009 and 2017, the rents for secondary sublet properties increased by $59 \%$ and for cooperative flats by $84 \%$. This was 3-4 times more than the increase in household incomes. As a result, more and more single parent families are forced to double up with friends or family or can only afford to rent a single room in a shared flat (Boverket, Uppdrag att följa utvecklingen). Lacking secure tenancies or contracts they are not eligible for housing benefits. Families that live under such circumstances are not officially counted as homeless and overall, knowledge about numbers of families affected and their living circumstances is limited (Samzelius, Family homelessness; Listerborn).

An increasing number of families, the vast majority headed by a single mother, are turning to social services for help. Those categorized as in 'acute homelessness' during a week of national mapping in 2017 had increased by $60 \%$ since the previous count six years earlier (Socialstyrelsen). However, unlike the UK, in Sweden there is no statutory duty to assist families that are at risk of homelessness. Instead, we are seeing a worrying trend where families with children are categorised as only eligible for short-term emergency assistance, expected to solve their own housing situation on the sublet market. This includes survivors of domestic violence, who are only entitled to short-term support in acute situations. When leaving a women's shelter, they are expected to find housing by themselves (Ekström). Those who fail to find

Feminismo/s 35, junio 2020, pp. 127-153 
Through the lens of single parenthood: a comparative snapshot of the impact of neoliberal welfare, housing and employment policies on single mothers in the UK and Sweden

housing through this route are, in greater Stockholm for example, pushed to take up housing offered by «slum landlords» in the Swedish countryside far away from social networks and with few employment opportunities. Wealthy urban local authorities tend to use the «housing shortage» as an excuse for pushing poor residents into other municipalities. The intersection between inadequate income protection, poor employment conditions, inadequate housing options and the lack of response from public authorities are thereby contributing to the destitution of vulnerable single mothers and children (Samzelius, Family homelessness).

\section{$5.2 \mathrm{UK}$}

In the UK the financialization of housing, together with the longer term trend that began in the Thatcher period of selling off social housing in less prosperous neighbourhoods, is leading to increasing gentrification in areas where many one parent families have settled. Single parent households based in high rent areas in major cities in the South of England for example, have become victims of growing gentrification, leading to their displacement, often to other parts of the country, dislocated from schools, family and friends. This is because more recent welfare reforms have seen the introduction of both a «bedroom tax» limiting the number of bedrooms a family is entitled to, and a housing benefit cap limiting the amount that can be claimed in high rent areas. Some tens of thousands of low-income families are forced out of their long-term homes, so that the properties can either be sold, or rented at market prices, seen by some as a form of «social cleansing» (Taylor 1). Given that one-parent families are more likely than ever to live in rented accommodation single parents are more likely to be subject to the benefit cap in high rent areas.

The intersection of housing and social security regulations is proving overtly discriminatory to single parents with children under 5. In a perverse ruling, single parents can escape the housing benefit cap if they work over 16 hours a week. But this applies to all single parents whatever the age of the children. Thus, the reality for single parents with children under school age is that they either have to work over 16 hours a week, or if they do not have access to childcare, they are forced to either move outside of their area 
Through the lens of single parenthood: a comparative snapshot of the impact of neoliberal welfare, housing and employment policies on single mothers in the UK and Sweden

and/or be made homeless. 38,390 single parent families were made homeless after the introduction of the cap, accounting for $63 \%$ of all homeless families, a rise of 54\% over the five-year period from when the benefit cap was first introduced. (Cohen, The Punitive Impact; Rich 2018).

According to data from Gingerbread, under legacy benefits, three-quarters (76\%) of these capped single parents' youngest children were of pre-school age (under five years) and therefore not subject to full job-seeking conditions under work-related benefit rules, despite the government's intentions with the benefit cap. A third (31\%) of capped single parents had a youngest child aged two or under. (Benefit-cap 1-2)

Single mothers with experience of abuse are particularly at risk, increasingly isolated by welfare and housing policies from the supportive social networks that have often proved critical to leaving abusive relationships. The association between single parenthood and abuse is too rarely made. Many members of SPAN became single parents in order to escape violence and abuse. In 2018, 52\% of respondents answering a questionnaire on singleparents.org.uk, a website set up by SPAN, cited domestic violence and abuse as the cause of their single parenthood.

The Office of National Statistics reported that a fifth (20.5\%) of single women with children said they had experienced abuse from a partner in the previous 12 months, compared with 4.9 per cent of women living with other adults and children (ONS, Domestic abuse). The period when a woman is planning or making her exit is often the most dangerous time for her and her children (Femicide Census 9). Many mothers are not alive today because they were not able to leave their partners.

The inability of low-income mothers experiencing abuse to forge and sustain independent female-headed households is resulting in either homelessness or continuing entrapment in abusive relationships. Women are more likely to go back to an abusive partner if they are living in poverty. Under austerity major cuts in publically funded support services are taking their toll. $64 \%$ of refuge referrals were declined in 2019 (Women's Aid 33). If women do leave, many end up homeless.

This is particularly the case for migrant mothers, many of whom came into the UK on family visas, dependent on a male partner that can increase the likelihood of coercion and violence. Those mothers declined places in a 
Through the lens of single parenthood: a comparative snapshot of the impact of neoliberal welfare, housing and employment policies on single mothers in the UK and Sweden

refuge are very often migrant women with «No Recourse to Public Funds» (NRPF) status: The options left to them - return to the abuser, dependency on friends and acquaintances, or other risky means of survival (Reis, Migrant Women 7).

\section{WAYS FORWARD FOR A MORE GENDER EQUAL SOCIETY? FOCUSING THE LENS ON SINGLE PARENT MOTHERS}

The level to which single parents are able to establish and maintain independent households is a good indication of the level of equality within society with regard to gender, ethnicity, class, disability, and citizenship status. The fact that the UK is doing so poorly in these arenas, explains why one parent families are faring so badly given the impact of intersectionality on their life chances (Hall et al.). Although not on the same scale, one parent families in Sweden are beginning to face comparable exclusions. The detail and history of welfare reform may differ between the two countries: Single parents in the UK are now more highly regulated and controlled by social security systems than at any other time in the history of welfare delivery. In Sweden, the retrenchment of the welfare state is leading to the most marginalised one parent families falling through the safety net. More generally however, the broader trajectories of welfare reform, liberalization of the housing market and the increase in single parent poverty are not that dissimilar, in spite of Sweden's more gender-equal back-story.

Equality protections for new migrants have been downgraded in both countries. We are seeing the largest migration of peoples across the world since the Second World War, yet very little research has been undertaken on the intersectional impact of housing, social welfare and employment policies on refugee and migrant single parent families in the UK and Sweden, or indeed in other EU countries. Research critical to progressing women's economic and social independence in any given country will need to take these changing demographics into account. Otherwise, furthering gender equality even in more gender equal settings will inevitably be partial, and of benefit to women who are established citizens already well protected by employment and economic and social infrastructures, whilst excluding those outside of those protections. 
Through the lens of single parenthood: a comparative snapshot of the impact of neoliberal welfare, housing and employment policies on single mothers in the UK and Sweden

We can see that in Sweden, with the protections of state feminism complacency may have set in. Here the Nordic model is not immune to the neo-liberal policies of the housing market, the racialization of the labour market and the feminization of poverty. If we look at welfare to work and housing policies through the lens of single parenthood, we see in this snapshot a very different picture to the more gender equal society that Sweden has been famed for.

Many feminists are developing socio/economic strategies over and above what it takes to succeed in the labour market. The Women's Budget Group (WBG) in the UK prioritises the Reproductive Economy as the way forward whereby giving and receiving care is central to life, central to being human, and central to the economy. In a neoliberal economic construct, GDP fails to take account of women's reproductive and caring roles. If we deconstruct the economy, we see that it is underpinned by the production and reproduction of people; that the unpaid work of women is central not only to the economy, but to the well-being of children and future generations. (Women's Budget Group, What is Feminist Economics?; Pearson).

Countering the intersectional discriminations of gender, class, ethnicity, citizenship and disability will be central to the restructuring of socio/economic infrastructures in a reproductive/care economy. Single mothers can be seen as ciphers in this respect. Focusing the lens on single mothers and the strategies needed to develop autonomous households, becomes a feminist way forward, given that multiple discriminations are much more likely to intersect in one parent families than in two parent families.

Our vision for the future, and the contribution of this article to wider debate therefore is for female headed households and mothers more generally, no matter their class, ethnicity or status, to have greater control in furthering their own and their families' well being and life chances.

\section{REFERENCES}

Alm, Susan, Kenneth Nelson, and Rense Nieuwenhuis. «The Diminishing Power of One? Welfare State Retrenchment and Rising Poverty of Single-Adult Households in Sweden 1988-2011». European Sociological Review (2019): 1-20. DOI: $10.1093 /$ esr/jcz053 
Through the lens of single parenthood: a comparative snapshot of the impact of neoliberal welfare, housing and employment policies on single mothers in the UK and Sweden

Andersson, Roger and Lena Magnusson Turner. «Segregation, gentrification, and residualisation: from public housing to market-driven housing allocation in inner city Stockholm». International Journal of Housing Policy 14. 1 (2014): 3-29. DOI: 10.1080/14616718.2013.872949

Annesley, Claire. State Feminism in New «Adult Worker Model» Welfare States? Paper presented to the ECPR Joint Sessions of Workshops. April 14-19, 2005. Web. 7 May 2020. https://ecpr.eu/Filestore/PaperProposal/aaf80081-2d7b4780-a8d4-e192c61ee8df.pdf

Baptista, Isabel. «Women and Homelessness». In Homelessness Research in Europe. Eds. Eoin O'Sullivan, Volker Busch Geertsema, Deborah Quilgars and Nicholas Pleace. Brussels: FEANTSA, 2016. 163-186

Baptista, Isabel, Lars Benjaminsen, Volker Busch-Geertsema, and Nicholas Pleace. Family homelessness in Europe. EHO Comparative Studies on Homelessness. Brussels: European Observatory on Homelessness, 2017. https://www.feantsaresearch.org/download/feantsa-studies_07_web3386127540064828685.pdf Boverket. Boende till rimlig kostnad Hushållens boendeutgiftsprocent och konsumtionsutrymme. Rapport 2016: 11.

https://www.boverket.se/globalassets/publikationer/dokument/2016/ boende-till-rimlig-kostnad.pdf

Boverket. Uppdrag att följa utvecklingen på andrahandsmarknaden. Rapport 2018: 29. https://www.boverket.se/globalassets/publikationer/dokument/2018/ utvecklingen-pa-andrahandsmarknaden.pdf

Beck, Ulrich, and Elisabeth Beck-Gernsheim. Individualization: Institutionalized Individualism and Its Social and Political Consequences. London: SAGE Publications, 2002.

Bezanson, Kate. Gender, the State, and Social Reproduction: Household Insecurity in Neo-liberal Times. Toronto: University of Toronto Press, 2006.

Bretherton, Joanne. «Reconsidering Gender in Homelessness». European Journal of Homelessness 11. 1 (2017): 1-21.

Cain, Ruth. «Responsibilising recovery: Lone and low-paid parents, Universal Credit and the gendered contradictions of UK welfare reform». British Politics. 11. 4 (2016): 488-507.

Calder, Gideon. «Social justice, single parents and their children». In The triple bind of single-parent families. Resources, employment and policies to improve wellbeing. Eds. Rense Nieuwenhuis and Laurie C. Maldonado. Bristol: Policy Press, 2018. 
Through the lens of single parenthood: a comparative snapshot of the impact of neoliberal welfare, housing and employment policies on single mothers in the UK and Sweden

Christophers, Brett. «A Monstrous Hybrid: The Political Economy of Housing in Early Twenty-first Century Sweden». New Political Economy 18. 6 (2013): 885-911.

Cohen, Sue. The Punitive Impact of Universal Credit on the Life Chances of Single Parents with Children Under 5. Women's Budget Group 13th May 2019. Web 7 May 2020.

Cohen, Sue, Allan Herbert, Nathan Evans, and Tove Samzelius. «From poverty to life chances: framing co-produced research in the Productive Margins programme». In The impact of co-production: From community engagement to social justice. Ed. Aksel Ersol. Bristol: Policy Press, 2017. 61-84.

Coleman, Nick, and Lorraine Lanceley. Lone parent obligations: supporting the journey into work. Department of Work and Pensions (DWP), 2011. https:// dera.ioe.ac.uk/3010/1/rrep736.pdf

Dwyer, Peter. Welfare rights and responsibilities: Contesting social citizenship. Bristol: Policy Press, 2000.

Ekström, Veronica. «Behovet av stöd till våldsutsatta kvinnor». In Manifest för ett social arbete i tiden. Eds. Magnus Dahlstedt and Philp Lalander. Lund: Studentlitteratur, 2018. 113-124.

Elliott, Larry. «Gordon Brown: I didn't think I'd see child poverty again in my lifetime.» Guardian 14 December 2018. Web. March 172020.

Feldman, Guy. «Neo liberalism and poverty: An unbreakable relationship». In Routletdge International Handbook of poverty. Ed. Bent Greve. London: Routledge, 2019. 340-350.

Femicide Census, 2018. Web. May 7 2020. https://femicidescensus.org/wp-content/uploads/2020/02/Femicide-Census-Report-on-2018-Femicides-.pdf

Försäkringskassan. Barnhushållens ekonomi - resultatindikatorer för den ekonomiska familjepolitiken, 2018. https:/www.forsakringskassan.se/wps/wcm/connect/ bbfe2133-a360-4a7f-b1d5-27e8db8d0ec4/barnhushallens-ekonomi-2018. pdf?MOD=AJPERES

Fraser, Nancy. «Women, Welfare and the Politics of Need Interpretation». Hypatia 2. 1 (1987): 103-121.

Fraser, Nancy. «Capitalism's Crisis of Care». Dissent 63.4 (2016): 30-37.

Fraser, Nancy. «Crisis of Care? On the Social-Reproductive Contradictions of Contemporary Capitalism». In Social Reproduction Theory : Remapping Class, Recentering Oppression. Eds. Tithi Bhattacharya and Lise Vogel. London: Pluto Press, 2017. 
Through the lens of single parenthood: a comparative snapshot of the impact of neoliberal welfare, housing and employment policies on single mothers in the UK and Sweden

Fritzell, Johan, Michael Gähler and Magnus Nermo. »Vad hände med 1990-talets stora förlorargrupper? Välfärd och ofärd under 2000-talet.» Socialvetenskaplig tidskrift 14. 2-3 (2007): 110-33.

Fudge, Judy, and Brenda Cossman, eds. Privatization, Law and the Challenges to Feminism. Toronto: Toronto University Press, 2002.

Gähler, Michael. »Bara en mor: ensamstående mödrars ekonomiska levnadsvillkor i 1990-talets Sverige». In Ofärd i Välfärden. Ed. Ake Bergmark. Stockholm: Fritzes (SOU 2001: 54). 15-97-

Giddens, Anthony. Modernity and self-identity: Self and society in the late modern age. Stanford: Stanford University Press, 1991.

Gingerbread. Employment and skills policy work. Sept 2019. Web. 5 May 2020. https://www.gingerbread.org.uk/policy-campaigns/employment-and-skills/ Gingerbread. Benefit-cap enquiry submission. 10 Sept 2018. Web. 8 March 2020. https://www.gingerbread.org.uk/policy-campaigns/publications-index/benefit-cap-inquiry-gingerbread-written-submission-work-pensions-select-committee/

Gray, Paul, and Nicholas Timmins. Reforming working-age social security: lessons for policy makers. IfG INSIGHT. June 2018. https://www.instituteforgovernment.org.uk/sites/default/files/publications/working-age-social-security-final. pdf

Gregg, Paul, Susan Harkness, and Sarah Smith. «Welfare Reform and Lone Parents in the UK». The Economic Journal 119. 535 (2009): 38-65.

Hall, Sarah-Marie, Kimberly McIntosh, Eva Neitzert, Laura Pottinger, Kalwinder Sandhu, Mary-Ann Stephenson, Howard Reed, and Leonie Taylor. Intersecting Inequalities: The impact of austerity on Black and Minority Ethnic women in the UK. WBG \& The Runnymede Trust, 2017. http://wbg.org.uk/wp-content/ uploads/2018/08/Intersecting-Inequalities-October-2017-Full-Report.pdf

Harkness, Susan. "The Effect of Employment on the Mental Health of Lone Mothers in the UK Before and After New Labour's Welfare Reforms». Social Indicators Research 128. 2 (2016): 763-791.

Haux, Tina, Debra Salmon, Lucy Taylor, Toity Deave, Sue Cohen, Laura Dewar, and Tove Samzelius. A longitudinal qualitative study of the journey of single parents on Jobseeker's Allowance. Project report. University of the West of England and Single Parent Action Network, 2012. Journal of Poverty and Social Justice 20. 3: 337-342. DOI: 10.1332/175982712X657172

Hjort, Torbjörn, ed. Det yttersta skyddsnätet. Lund: Studentlitteratur, 2019. 
Through the lens of single parenthood: a comparative snapshot of the impact of neoliberal welfare, housing and employment policies on single mothers in the UK and Sweden

Hobson, Barbara, and Masahide Takahashi. «The Parent-worker Model: Lone Mothers in Sweden». Lone Mothers in European Welfare Regimes: Shifting Policy Logics. Ed. Jane Lewis. London: Jessica Kingsley, 1997. 121-139.

Jaehrling, Karen, Thorsten Kalina, and Leila Mesaros. «A Paradox of Activation Strategies: Why Increasing Labour Market Participation among Single Mothers Failed to Bring Down Poverty Rates». Social Politics: International Studies in Gender, State \& Society 22. 1 (2015): 86-110.

Joseph Rowntree Foundation. UK Poverty 2018: a comprehensive analysis of poverty trends and figures. Web. April 172020.

Joseph Rowntree Foundation. Budget 2018: Tacking the rising tide of in-work poverty. jrf.org.uk, 12 ${ }^{\text {th }}$ Oct 2018. Web. April 172020.

Joseph Rowntree Foundation. UK Poverty 2019/20: Work. 2020. Web. April 17 2020.

Kiernan, Kathleen, Hilary Land, and Jane Lewis. Lone Motherhood in TwentiethCentury Britain. Oxford: Clarendon Press, 1998.

Lewis, Jane, ed. Lone Mothers in European Welfare Regimes: Shifting Policy Logics. London: Jessica Kingsley, 1997.

Lister, Ruth. «She Has Other Duties- Women, Citizenship and Social Security.» In Social Security and Social Change: New Challenges to the Beveridge Model. Eds. Sally Baldwin and Jane Falkingham. New York; London: Harvester Wheatsheaf, 1994. 31-44.

Listerborn, Carina. Bostadsojämlikhet. Röster om bostadsnöden. Falun: Premissförlag, 2017.

MacLeavy, Julie. "A 'new politics' of austerity, workfare and gender? The UK coalition government's welfare reform proposals». Cambridge Journal of Regions, Economy and Society, 4. 3 (November 2011): 355-367. https://doi. org/10.1093/cjres/rsr023

Mayock, Paula, Joanne Bretherton, and Isabel Baptista. «Women's Homelessness and Domestic Violence: (In) visible Interactions». Eds. Paula Mayock and Joanne Bretherton. Women's Homelessness in Europe. London: Palgrave MacMillan, 2016. 125-152.

McDermont Morag, Tim Cole, Janet Newman, Angela Piccini (eds.) Imagining regulation differently, Co-creating for engagement. Bristol: Policy Press, 2020. Mik-Meyer, Nanna, and Kaspar Villardsen. Power and Welfare: Understanding Citizens' Encounters with State Welfare. Hoboken: Taylor and Francis, 2012. 
Through the lens of single parenthood: a comparative snapshot of the impact of neoliberal welfare, housing and employment policies on single mothers in the UK and Sweden

Millar, Jane, and Tessa Ridge. Families, poverty, work and care: A review of the literature on lone parents and low-income couple families with children. Research Report No. 153. Department for Works and Pensions. 2001. https://dera.ioe. ac.uk/10096/. Web. April 172020.

Millar, Jane, and Fran Bennett. «Universal Credit: Assumptions, contradicitons and virtual reality». Social Policy and Society 1 (2017): 169-182.

Murphy, Mary. «Dual conditionality in welfare and housing for lone parents in Ireland: Change and continuity?» Social Policy and Administration 54. 2 (2019): 250-264.

Näsman, Elisabeth. «Barnperspektiv på ekonomiskt bistånd». In Det yttersta skyddsnätet. Ed. Torbjörn Hjort. Lund: Studentlitteratur, 2019. 247-266.

Office for National Statistics. Families and the Labour Market UK. ONS, 2019. Web. 17 April 2020.

Office for National Statistics. Domestic Abuse: findings from the crime survey for England and Wales. ONS, 2018. Web. 17 April 2020.

Panican, Andreu, and Richard Ulmestig. «Social rights in the shadow of poor relief - social assistance in the universal Swedish welfare state». Citizenship Studies 20. 3-4 (2016): 475-489.

Pearce, Diane. «The Feminization of Poverty: Women, Work, and Welfare». Urban and Social Change Review 11. 1-2 (1979): 28-36.

Pearson, Ruth. «A feminist analysis of neoliberalism and austerity policies in the UK». Soundings 71. Neoliberalism, feminism and transnationalism. Spring 2019. DOI: 10.3898/SOUN.71.02.2019.

Pleace, Nicholas. «Family Homelessness in Europe». Homeless in Europe, The Magazine of FEANTSA (Autumn 2019): 22-23.

Rabindrakumar, Sumi. On the Rise - Single Parent Sanctions in Numbers. Gingerbread, April 2017. Web. April 172020.

Reis, Sara. A home of her own: Housing and women. WBG, July 2019. https://wbg. org.uk/wp-content/uploads/2019/07/WBG19-Housing-Report-full-digital.pdf

Reis, Sara. Migrant Women and the Economy. WBG, May 2020. https://wbg.org.uk/ wp-content/uploads/2020/05/WBG-28-Migrant-Women-Report-v3-Digital. pdf

Rich, Hannah. The Full Extent of the Homelessness Crisis. Shelter blog, July 2018. Web. April 172020. 
Through the lens of single parenthood: a comparative snapshot of the impact of neoliberal welfare, housing and employment policies on single mothers in the UK and Sweden

Roman, Christine. "Gendered and classed experiences of work-family conflict among lone mothers in Sweden». Community, Work \& Family, 22.3 (2019). DOI: $10.1080 / 13668803.2018 .1456404$

Rowlingson, Karen, and Stephen Mckay. Lone Parent Families: Gender, Class and State. London: Routledge, 2014: 30.

Sainsbury, Diane, and Anne Morissens. «Sweden: The Feminization of Poverty?». Poor Women in Rich Countries: The Feminization of Poverty Over the Life Course. Ed Gertrude Schaffner Goldberg. Oxford Scholarship Online, February 2010. Salonen, Tapio. Övervältringar från Socialförsäkringar till Socialbidrag. Lund: Meddelanden från Socialhögskolan, 1997.

Salonen, Tapio. Välfärd inte för alla. Stockholm: Rädda Barnen, 2019.

Samzelius, Tove. En plats att kalla hemma: Barnfamiljer i bostadskrisens skugga. Stockholm: Rädda Barnen, 2017.

Samzelius, Tove. «Ensamstående mammor och rätten till bostad.» Manifest för ett social arbete i tiden. Eds. Magnus Dahlstedt and Philp Lalander. Lund: Studentlitteratur, 2018. 113-124.

Samzelius, Tove. Family homelessness and poverty in Sweden: A single mother perspective. PhD Dissertation, Malmö University. Forthcoming 2020.

Select Committee on Work and Pensions Memorandum. Memorandum submitted by Single Parent Action Network, Sept 2006. Web. 7 May 2020. https://publications.parliament.uk/pa/cm200506/cmselect/cmworpen/1649/1649m12.htm Smith George, Kathy Sylva, Teresa Smith, Pam Sammons and Aghogho Omonigho Stop/Start. University of Oxford and the Sutton Trust, 2018. Web. 17 April 2020.

Socialstyrelsen. Öppna jämförelser av hemlöshet och utestängning från bostadsmarknaden. Enkätundersökning 2016. Stockholm: Socialstyrelsen, 2017.

SPAN. A hands on history project. 2019. Web. 7 May 2020. www.thespanproject. org.uk

Stranz, Hugo, and Stefan Wiklund. «Ekonomiskt bistånd i särskilda grupper exemplet ensamstående kvinnor med barn». Det yttersta skyddsnätet. Ed. Torbjörn Hjort. Lund: Studentlitteratur, 2019. 269-288.

Sunesson, Sune, Stefan Blomberg, Per Gunnar Edebalk, Lars Harrysson, Jan Magnusson, Anna Meeuwisse, Jan Petersson, and Tapio Salonen. «The flight from universalism». European Journal of Social Work 1. 1 (1998): 19-29.

Taylor, Matthew. «Vast 'social cleansing' pushes tens of thousands of families out of London». Guardian. 28 August 2015. 
Through the lens of single parenthood: a comparative snapshot of the impact of neoliberal welfare, housing and employment policies on single mothers in the UK and Sweden

Treanor, Morag. Child Poverty: Aspiring to Survive. Bristol: Policy Press, 2020. Van Lanker, Wim. «Does the use of reconciliation policies enable single mothers to work? A comparative examination of European countries». In The triple bind of single-parent families: Resources, employment and policies to improve wellbeing. Eds. Rense Nieuwenhuis and Laurie C. Maldonado. Bristol: Policy Press, 2018.

Warburton, Wayne, Elisabeth Whittaker, and Marina Papic. «Homelessness Pathways for Australian Single Mothers and Their Children: An Exploratory Study». Societies 8.16 (2017): 1-22.

Watt, Paul. «Gendering the right to housing in the city: Homeless female lone parents in post-Olympics, austerity East London». Cities 76 (2018): 43-51.

Webb, Roger. «Neoliberal welfare reform and single parents mental health». The Lancet. Public Health 3. 7 (1 July 2018). Web. 7 May 2020. https://doi. org/10.1016/S2468-2667(18)30116-6

Wennberg, Lena. Social Security for Swedish Solo-Mothers in Swedish and EU Law: On the Constructions of Normality and the Boundaries of Citizenship. Umea: Iustus förlag, 2008.

Withworth, Adam and Julia Griggs. «Lone Parents and Welfare-to-work Conditionality: Necessary, Just, Effective?» Ethics and Social Welfare 7. 2 (2013): 124-140.

Women's Aid. The Domestic Abuse Report 2020: The Annual Audit. Bristol: Women's Aid, 2020.

Women's Budget Group. What is Feminist Economics? 10 January 2018. Web. 17 April 2020. http://wbg.org.uk/wp-content/uploads/2018/08/WBG-What-isFem-Ec-PDF-v3-1.pdf

Women's Budget Group. Migrant women and social security. 20 March 2020. Web. 17 April 2020. https://wbg.org.uk/wp-content/uploads/2020/03/finalmigrant-women-2020.pdf

Wright, Polly, and Susanna Giullari. Proofed for Parents by Parents Participatory One Parent Proofing: Toolkit. Millpond, Bristol: SPAN, 2007. https://opfs. org.uk/wp-content/uploads/2020/02/Participatory_One_Parent_Proofing_ Toolkit.pdf 